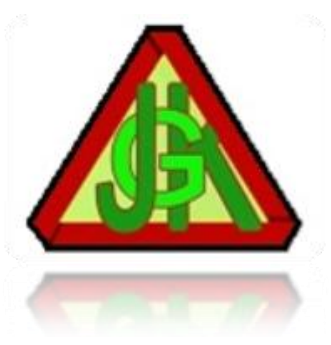

\title{
TINGKAT AKTIVITAS FISIK BERHUBUNGAN DENGAN TEKANAN DARAH PEKERJA DI RUMAH SELAMA MASA PANDEMI COVID-19
}

\author{
Ni Made Wedri ${ }^{1}$, Komang Ayu Windayanti ${ }^{2}$, IGA Ari Rasdini ${ }^{3}$ \\ 1,2,3 Politeknik Kesehatan Kemenkes Denpasar \\ Bali, Indonesia \\ Email :wedri87@gmail.com ${ }^{1}$, ayuwindayanti13@gmail.com ${ }^{2}$, \\ rasdiniari@gmail.com ${ }^{3}$
}

\begin{abstract}
Abstrak
Hipertensi atau tekanan darah tinggi adalah keadaan dimana seseorang mengalami peningkatan tekanan darah diatas normal dimana tekanan sistolik mencapai $\geq 140$ $\mathrm{mmHg}$ dan tekanan diastolik $\geq 90 \mathrm{mmHg}$. Faktor-faktor yang mempengaruhi hipertensi salah satunya yaitu aktivitas fisik. Aktivitas fisik bisa dilakukan di rumah, di tempat kerja, di sekolah dan bisa melakukan aktivitas untuk mengisi waktu luang. Kurangnya aktivitas fisik dapat meningkatkan risiko menderita hipertensi. Penelitian ini bertujuan untuk mengetahui hubungan tingkat aktivitas fisik dengan tekanan darah pada pekerja yang bekerja dari rumah selama masa pandemi Covid-19. Metode penelitiannya analitik korelasi dengan pendekatan cross sectional. Sampel penelitian berjumlah 68 orang menggunakan teknik sampling probability sampling. Instrumen pengumpulan data menggunakan kuesioner IPAQ dan pengukuran tekanan darah menggunakan spigmomanometer. Hasil penelitian menunjukkan sebagian besar responden memiliki aktivitas fisik sedang sejumlah 31 orang $(45.6 \%)$ dan tekanan darah responden pada kategori normal sejumlah 26 orang $(38.2 \%)$. Hasil uji menggunakan rank spearman dengan nilai $\rho$-value $=0.004<\alpha(0.05)$ dan nilai $\mathrm{r}=-0,348$ korelasi bernilai negatif yang berarti semakin tinggi tingkat aktivitas fisik maka semakin turun tekanan darah. Dapat disimpulkan bahwa ada hubungan tingkat aktivitas fisik dengan tekanan darah pada pekerja yang bekerja dari rumah selama masa pandemi Covid-19 di wilayah Kelurahan Seririt tahun 2021.
\end{abstract}

Kata kunci: Aktivitas fisik, Tekanan darah, Pekerja

\begin{abstract}
Hypertension or high blood pressure is a condition in which a person experiences an increase in blood pressure above normal where the systolic pressure reaches $140 \mathrm{mmHg}$ and the diastolic pressure reaches $90 \mathrm{mmHg}$. One of the factors that influence hypertension is physical activity. Physical activity can be done at home, at work, at school and can do activities to fill spare time. Lack of physical activity can increase the risk of suffering from hypertension. This study aims to determine the relationship of physical activity levels with blood pressure in workers who working from home during the Covid-19 pandemic. The research method was
\end{abstract}


correlation analytics with cross sectional approach. The research sample numbered 68 people using sampling probability sampling technique. Data was collected by instruments IPAQ questionnaires and blood pressure measurements using sphygmomanometer. The results showed that most respondents had moderate physical activity in 31 people (45.6\%) and blood pressure of respondents in the normal category of 26 people (38.2\%). The test results used spearman rank with a value of $0.004<\alpha(0.05)$ and a value of $r=-0.348$ The correlation is negative, which means that the higher the level of physical activity, the lower the blood pressure. It can be concluded that there is a relationship between the level of physical activity and blood pressure in workers who work from home during the Covid-19 pandemic in the Seririt Village area in 2021.

Keywords: Physical activity, Blood pressure, Workers, Covid-19

\section{PENDAHULUAN}

Hipertensi atau yang sering disebut darah tinggi merupakan salah satu penyakit tidak menular yang merupakan masalah di Indonesia. Hipertensi atau yang lebih dikenal dengan sebutan penyakit tekanan darah tinggi adalah keadaan dimana seseorang dinyatakan mengalami peningkatan tekanan darah di atas batas normal. Seseorang dinyatakan mengalami penyakit hipertensi bila tekanan sistolik mencapai di atas $140 \mathrm{mmHg}$ dan tekanan diastolik di atas $90 \mathrm{mmHg}^{(1)}$. Faktorfaktor yang mempengaruhi terjadinya hipertensi dibagi menjadi dua kelompok yaitu faktor yang tidak dapat dikendalikan seperti jenis kelamin, umur, genetik, ras dan faktor yang dapat dikendalikan yaitu pola makan, aktivitas fisik, konsumsi garam, kopi, merokok, alkohol dan stress.

Kasus hipertensi di Provinsi Bali mengalami penurunan secara bertahap dari tahun 2014 sampai tahun 2017 meskipun demikian kasus hipertensi primer tetap menduduki peringkat kedua dari sepuluh besar penyakit yang banyak di derita di seluruh puskesmas di Provinsi Bali. Tahun 2014 jumlah penderita hipertensi primer tercatat sebanyak 114.421 orang $^{(2)}$. Penurunan terjadi di tahun 2017 dengan jumlah penderita hipertensi primer sebanyak 60.665 orang di seluruh puskesmas di Provinsi Bali ${ }^{(3)}$. Data yang didapat dari Dinas Kesehatan Kabupaten Buleleng menunjukkan bahwa hipertensi primer berada pada peringkat pertama dalam sepuluh besar penyakit yang ada di Kabupaten Buleleng tahun 2019. Tercatat sebanyak 13.765 terjadi pada laki-laki dan 16.823 terjadi pada perempuan dimana jumlah keseluruhanya itu 30.588 penderita hipertensi 
Ni Made Wedri, Komang Ayu Windayanti, IGA Ari Rasdini. Juni 2021. 14 (1): $16-26$

primer $^{(4)}$. Data yang didapat dari puskesmas Kecamatan Seririt menunjukkan bahwa hipertensi berada pada peringkat pertama dalam sepuluh besar penyakit yang ada di puskesmas Kecamatan Seririt. Tercatat sebanyak 2.928 jumlah kejadian hipertensi pada tahun 2017. Tahun 2018 kasus hipertensi mengalami sedikit penurunan yaitu sebanyak 2.881. Penurunan terjadi kembali pada tahun 2019 yaitu sebanyak 2.659 kasus hipertensi. Pada tahun 2020 terjadi peningkatan kasus hipertensi yaitu sebanyak 3.145.

Aktivitas fisik sangat penting untuk kesehatan tubuh manusia salah satunya untuk tekanan darah. Kurangnya aktivitas fisik meningkatkan risiko menderita hipertensi. Orang yang tidak aktif cenderung mempunyai frekuensi denyut jantung yang lebih tinggi sehingga otot jantungnya harus bekerja lebih keras pada setiap kontraksi, makin besar dan sering otot jantung memompa, maka makin besar tekanan yang dibebankan pada arteri sehingga tekanan darah akan meningkat ${ }^{(5)}$.

Riset Kesehatan Dasar (Riskesdas) tahun 2018 menunjukkan bahwa proporsi kurangnya aktivitas fisik di Indonesia mengalami kenaikan, pada tahun 2013 sebesar $26.2 \%$ dan naik menjadi $33.5 \%$ pada tahun 2018. Riskesdas menjelaskan kurangnya aktivitas fisik yaitu kegiatan kumulatif yang kurang dari 150 menit seminggu. Di Indonesia, tepatnya DKI Jakarta memiliki proporsi kurangnya aktivitas fisik yang tertinggi yaitu sebesar $47.8 \%{ }^{(6)}$.

Bekerja dari rumah yang sedang di jalankan pada masa pandemi Covid-19 merupakan tindak lanjut himbauan Presiden Jokowi. Hal ini disarankan agar dapat meminimalisasi penyebaran virus Covid-19. Masyarakat saat ini diminta untuk bekerja, belajar, beribadah dari rumah, dan salah satunya adalah sistem bekerja dari rumah.

Pada saat pandemi Covid-19 sangat penting untuk menjalankan program pemerintah untuk meningkatkan kekebalan tubuh dan terhindar dari Covid-19 program tersebut yaitu Gerakan Masyarakat Hidup sehat (GERMAS) dimana salah satunya yaitu melakukan aktivitas fisik. Menurut penelitian Dana (2018) didapatkan bahwa ada hubungan yang signifikan antara aktivitas fisik dengan derajat hipertensi ${ }^{7}$. Pada saat pandemi Penelitian ini bertujuan untuk mengetahui 
Ni Made Wedri, Komang Ayu Windayanti, IGA Ari Rasdini. Juni 2021. 14 (1): $16-26$

hubungan tingkat aktivitas fisik dengan tekanan darah pada pekerja yang bekerja dari rumah.

\section{METODE}

Metode penelitian yaitu analitik korelasi dengan pendekatan cross sectional. Sampel penelitian adalah 68 pekerja di Wilayah Kelurahan Seririt menggunakan teknik sampling probability sampling. Adapun kriteria sampel yang pilih yaitu Kriteria inklusi meliputi pekerja yang bekerja dari rumah dan pekerja dengan umur $\geq 25$ tahun (karyawan perusahaan pemerintah tahun 2019). Adapun kriteria ekslusi meliputi pekerja yang aktif merokok, pekerja yang mengkonsumsi alkohol, pekerja yang mengalami obesitas, pekerja yang memiliki riwayat penyakit diabetes melitus, pekerja yang tidak bersedia menjadi responden. Instrumen pengumpulan data menggunakan kuesioner IPAQ - short form dan pengukuran tekanan darah menggunakan spigmomanometer. Metode pengumpulan data dalam penelitian ini yaitu pertama melakukan pemeriksaan tekanan darah dengan spigmomanometer. Dilanjutkan dengan memberikan pertanyaan yang terstruktur sesuai dengan yang ada di kuesioner. Analisa data menggunakan metode analisa univariat dan analisa bivariat.

\section{HASIL DAN PEMBAHASAN}

Karakteristik responden berdasarkan usia, jenis kelamin, dan pekerjaan disajikan dalam tabel 1 dibawah ini. 
Ni Made Wedri, Komang Ayu Windayanti, IGA Ari Rasdini. Juni 2021. 14 (1): $16-26$

Tabel 1. Karakteristik Responden Berdasarkan Usia, Jenis Kelamin, dan Pekerjaan

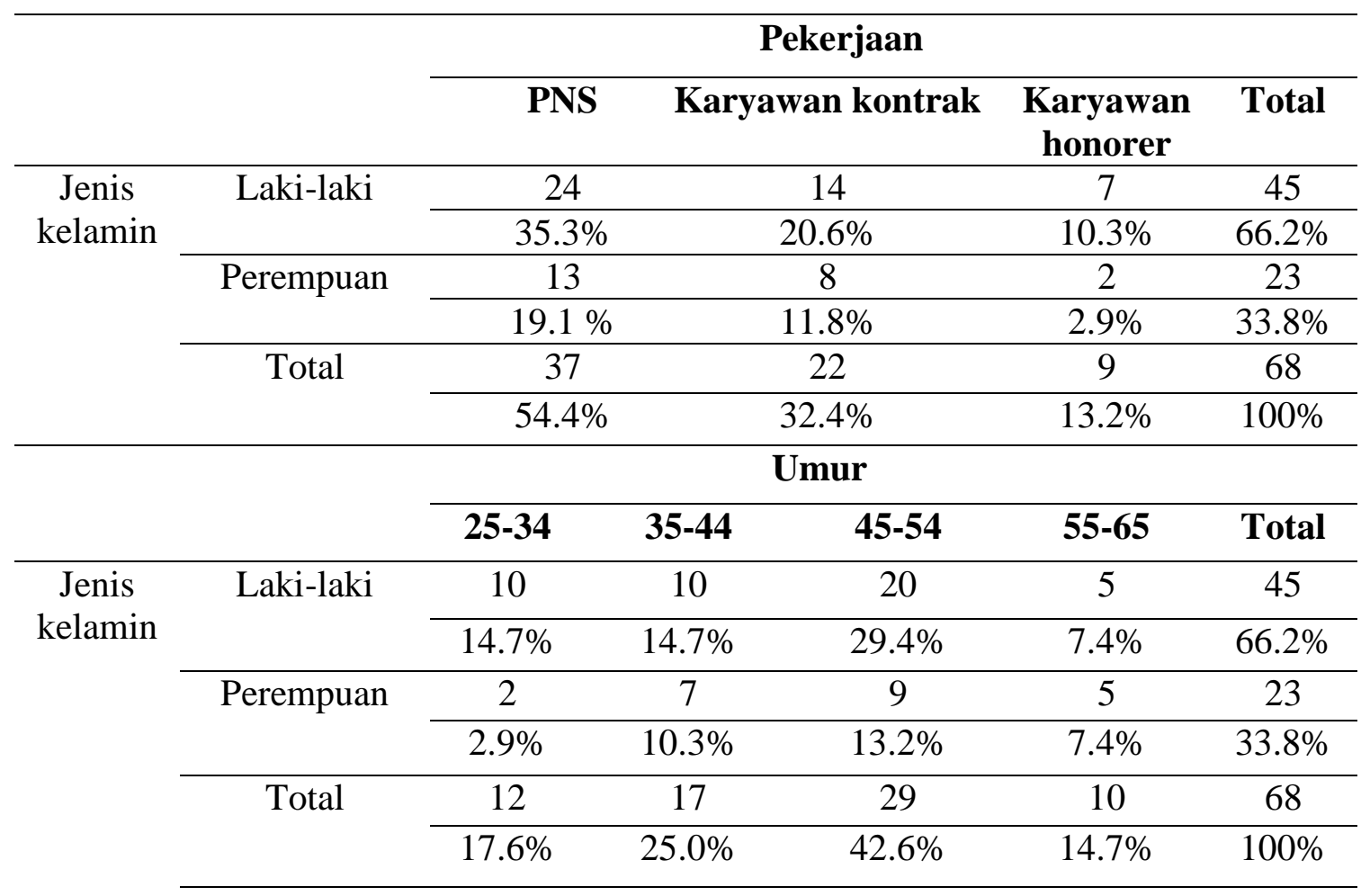

Tabel 1 menunjukkan jenis responden terbanyak yaitu laki-laki yang berusia 45-54 (29.4\%) dan pekerjaan sebagai PNS (35.3\%).

Hasil penelitian meliputi tingkat aktivitas fisik, tekanan darah, dan analisa data hubungan tingkat aktivitas dengan tekanan darah disajikan pada tabel 2 sampai dengan 4 di bawah ini.

Tabel 2. Distribusi Frekuensi Responden berdasarkan Tingkat Aktivitas Fisik

\begin{tabular}{ccc}
\hline Aktivitas fisik & n & \% \\
\hline Ringan & 25 & $36,8 \%$ \\
Sedang & 31 & $45,6 \%$ \\
berat & 12 & $17,6 \%$ \\
\hline Total & 68 & 100
\end{tabular}

Tabel 2 menunjukkan tingkat aktivitas fisik responden terbanyak sedang sebanyak 31 orang $(45,6 \%)$. 
Ni Made Wedri, Komang Ayu Windayanti, IGA Ari Rasdini. Juni 2021. 14 (1): $16-26$

Tabel 3. Distribusi Frekuensi Responden berdasarkan Tekanan Darah

\begin{tabular}{lcc}
\hline \multicolumn{1}{r}{ Tekanan Darah } & $\mathrm{n}$ & $\%$ \\
\hline Normal & 26 & $38,2 \%$ \\
Tinggi & 25 & $36,8 \%$ \\
Hipertensi stage 1 & 9 & $13,2 \%$ \\
Hipertensi stage 2 & 8 & $11,8 \%$ \\
\hline Total & 68 & 100 \\
\hline
\end{tabular}

Tabel 3 menunjukkan tekanan darah responden terbanyak normal sebanyak 26 orang $(38,2 \%)$.

Tabel 4. Analisa Data Hubungan Tingkat Aktivitas Fisik dengan Tekanan Darah

\begin{tabular}{|c|c|c|c|c|c|c|c|c|c|c|}
\hline \multirow{3}{*}{$\begin{array}{l}\text { Tekanan } \\
\text { darah }\end{array}$} & \multicolumn{10}{|c|}{ AktivitasFisik } \\
\hline & \multicolumn{2}{|c|}{ Ringan } & \multicolumn{2}{|c|}{ Sedang } & \multicolumn{2}{|c|}{ Berat } & \multirow{2}{*}{\multicolumn{2}{|c|}{ Total }} & \multirow{2}{*}{$\begin{array}{l}P \\
\text { value }\end{array}$} & \multirow[t]{2}{*}{$r$} \\
\hline & $\mathrm{N}$ & $\%$ & $\mathrm{~N}$ & $\%$ & $\mathrm{~N}$ & $\%$ & & & & \\
\hline Normal & 4 & 5,9 & 17 & 25 & 5 & 7,4 & 26 & 38,2 & 0,004 & - \\
\hline Tinggi & 10 & 14,7 & 9 & 13,2 & 6 & 8,8 & 25 & 36,8 & & 0,348 \\
\hline $\begin{array}{l}\text { hipertensi } \\
\text { stage } 1\end{array}$ & 6 & 8,8 & 2 & 2,9 & 1 & 1,5 & 9 & 13,2 & & \\
\hline $\begin{array}{l}\text { Hipertensi } \\
\text { stage } 2\end{array}$ & 5 & 7,4 & 3 & 4,4 & 0 & 0 & 8 & 11,8 & & \\
\hline Total & 25 & 36,8 & 31 & 45,6 & 12 & 17,6 & 68 & 100 & & \\
\hline
\end{tabular}

Tabel 4 menunjukkan bahwa hasil analisis tingkat aktifitas fisik dengan tekanan darah dengan $\mathrm{p}$-value $=0,004$ yang artinya ada hubungan tingkat aktivitas fisik dengan tekanan darah.

\section{Tingkat Aktivitas Fisik}

Hasil penelitian pada tabel 1 menunjukkan bahwa jenis kelamin responden terbanyak yaitu laki-laki yang berusia 45-54 tahun dengan persentase $29.4 \%$ dan pekerjaan sebagai PNS dengan persentase 35.3\%. Hasil penelitian pada tabel 2 menunjukkan bahwa tingkat aktivitas fisik yang dilakukan pekerja yaitu lebih banyak pada aktivitas fisik yang sedang sebanyak 31 responden dengan persentase 45.6\%. Aktifitas fisik sedang yang meliputi mengangkat barang ringan, membersihkan rumah, dan bersepeda santai. 
Ni Made Wedri, Komang Ayu Windayanti, IGA Ari Rasdini. Juni 2021. 14

(1): $16-26$

Bekerja dari rumah yang sedang dijalankan pada masa pandemi Covid-19 merupakan tindak lanjut himbauan Presiden Jokowi. Hal ini disarankan agar dapat meminimalisasi penyebaran virus Covid-19. Masyarakat saat ini diminta untuk bekerja, belajar, beribadah dari rumah, dan salah satunya adalah sistem bekerja dari rumah. Pada saat pandemi Covid-19 sangat penting untuk menjalankan program pemerintah untuk meningkatkan kekebalan tubuh dan terhindar dari Covid-19 program tersebut yaitu Gerakan Masyarakat Hidup sehat (GERMAS) dimana salah satunya yaitu melakukan aktivitas fisik.

Hasil penelitian ini berupa tingkat aktivitas fisik pekerja yang diukur dengan menggunakan kuesioner IPAQ. Pekerja mengisi sesuai dengan aktivitas yang dilakukan dalam satu minggu terakhir (self report). Kuesioner IPAQ terdiri dari beberapa indikator yang dapat mengukur tingkat aktivitas fisik. Indikatornya terdiri dari low, moderate, dan high. Low merupakan tingkat aktivitas fisik terendah, sedangkan moderate memiliki kriteria yang dapat diklasifikasikan sebagai berikut; tiga hari atau lebih kegiatan dengan intensitas tinggi setidaknya 20 menit per hari; lima hari atau lebih dari aktivitas intensitas sedang atau berjalan kaki minimal 30 menit per hari. Kategori high memiliki criteria sebagai berikut; aktivitas intensitas tinggi setidaknya tiga hari, mencapai total minimum aktivitas fisik minimal 1500 MET-menit/minggu; tujuh hari atau lebih dari setiap kombinasi berjalan, intensitas sedang atau aktivitas intensitas tinggi mencapai minimal total aktivitas fisik setidaknya 3000 MET-menit/minggu.

Manfaat aktivitas fisik di antaranya adalah menjaga tekanan darah dan kolesterol, menurunkan risiko penyakit jantung dan stroke, menjaga berat badan, menurunkan tingkat stress, memperkuat jantung dan memperbaiki sirkulasi darah, memperkuat tulang dan otot, menjaga fleksibilitas sendi, sertamenurunkan gejala depresi dan memperbaiki kualitas hidup ${ }^{(8)}$.

Aktivitas fisik yang dilakukan secara teratur akan meningkatkan ketahanan fisik atau tubuh. Cara untuk meningkatkan kebugaran serta kesehatan tubuh yaitu dengan latihan fisik ataupun olahraga secara teratur, yang bias dilakukan secara perorangan atau dalam bentuk kelompok. Aktivitas fisik juga bagian dari kehidupan setiap orang dewasa ataupun pekerja ${ }^{(9)}$. 
Ni Made Wedri, Komang Ayu Windayanti, IGA Ari Rasdini. Juni 2021. 14

(1): $16-26$

\section{Tekanan Darah}

Tekanan darah normal sangat dibutuhkan untuk mengalirkan darah ke seluruh tubuh, yaitu mengangkut oksigen dan zat-zat nutrisi yang penting untuk tubuh. Darah mengalir melalui pembuluh darah dan memiliki kekuatan untuk menekan dinding pembuluh darah tersebut, inilah yang disebut dengan tekanan darah. Tekanan darah terendah ada dalam pembuluh darah, sedangkan darah tertinggi ada dalam arteri terbesar ${ }^{(10)}$.

Penelitian ini menunjukkan bahwa responden paling banyak memiliki tekanan darah normal yaitu sebanyak 26 responden (38.2\%), meskipun demikian banyak juga responden yang memiliki tekanan darah dengan kategori pre hipertensi yaitu sebanyak 25 responden (36.8\%). Meningkatnya tekanan darah berkaitan dengan kerja organ jantung yang memompa lebih kuat sehingga volume cairan yang mengalir setiap detik bertambah besar, menebal dan kakunya arteri besar yang dapat terjadi karena penyumbatan pembuluh darah arteri (arteriosclerosis), dan kelainan fungsi ginjal sehingga tidak mampu membuang sejumlah garam dan air dalam tubuh ${ }^{(11)}$.

Penurunan tekanan darah juga dapat terjadi jika terdapat ketidakseimbangan antara kapasitas vaskuler dan volume darah atau jika jantung terlalu lemah untuk menghasilkan tekanan yang dapat mendorong darah ${ }^{(12)}$. Hipotensi dapat disebabkan oleh beberapa factor seperti dehidrasi, melemahnya otot jantung, terjadi peradangan pada pericardium, terjadinya pembekuan darah dalam pembuluh darah vena, denyut jantunglambat, pelebaran pembuluh darah, efek samping obat, kejutan emosional dan diabetes tingkat lanjut ${ }^{(13)}$.

\section{Hubungan Tingkat Aktivitas Fisik dengan Tekanan Darah}

Aktivitas fisik sangat penting peranannya bagi individu, dengan melakukan aktivitas fisik, maka individu dapat meningkatnya derajat kesehatanya. Aktivitas fisik yang teratur dapat membantu meningkatkan efisiensi jantung secara keseluruhan. Mereka yang aktif secara fisik umumnya mempunyai tekanan darah yang lebih rendah dan lebih jarang terkena tekanan darah tinggi. Mereka yang 
Ni Made Wedri, Komang Ayu Windayanti, IGA Ari Rasdini. Juni 2021. 14

(1): $16-26$

aktif secara fisik cenderung mempunyai fungsi otot dan sendi yang lebih baik, karena orang-orang demikian lebih kuat dan lentur.

Berdasarkan hasil penelitian yang dilakukan di Kelurahan Seririt didapatkan bahwa ada hubungan yang signifikan antara tingkat aktivitas fisik dengan tekanan darah dengan nilai $\rho$-value $=0.002<\alpha(0.05)$ yang artinya ada hubungan tingkat aktivitas fisik dengan tekanan darah pada pekerja yang bekerja dari rumah selama masa pandemi Covid-19 di wilayah Kelurahan Seririt tahun 2021.

Kurangnya aktivitas fisik meningkatkan risiko menderita hipertensi. Orang yang tidak aktif cenderung mempunyai frekuensi denyut jantung yang lebih tinggi sehingga otot jantungnya harus bekerja lebih keras pada setiap kontraksi, makin besar dan sering otot jantung memompa, maka makin besar tekanan yang dibebankan pada arteri sehingga tekanan darah akan meningkat ${ }^{(5)}$.

Aktivitas fisik yang dapat menstabilkan tekanan darah merupakan aktivitas fisik yang sederhana yaitu aktivitas fisik sehari-hari. Aktivitas fisik sehari-hari meliputi berdiri, bekerja, dan berjalan ${ }^{14}$. Aktivitas fisik yang terukur, benar, dan teratur dapat mengurangi risiko terjadinya penyakit tidak menular (PTM) dan dapat meningkatkan derajat kesehatan dan kebugaran jasmani. Aktivitas fisik juga melambatkan arterosklerosis dan menurunkan risiko serangan jantung dan stroke dimana aktivitas fisik dapat meningkatkan aliran darah ke jantung, menjaga elastisitas arteri dan fungsi $\operatorname{arterial}^{(15)}$.

Aktivitas fisik ringan secara independen mempengaruhi hipertensi. Semakin ringan aktivitas fisik semakin meningkatkan risiko terjadinya hipertensi. Aktivitas fisik ringan adalah segala sesuatu yang berhubungan dengan menggerakan tubuh. Aktivitas yang berupa gerakan atau latihan aerobic bermanfaat untuk meningkatkan dan mempertahankan kebugaran, ketahanan kardio-respirator. Aktivitas yang dilakukan berupa latihan-latihan aerobic adalah seperti berjalan, jogging, berenang, bersepeda. Latihan aerobic dapat membuat otot-otot tubuh bekerja.

Aktivitas fisik berpengaruh terhadap hipertensi. Semakin tinggi aktivitas fisik maka semakin kecil risiko terkena penyakit hipertensi. Seseorang dengan aktivitas ringan memiliki kecendrungan sekitar 30-50\% terkena hipertensi 
Ni Made Wedri, Komang Ayu Windayanti, IGA Ari Rasdini. Juni 2021. 14 (1): $16-26$

dibandingkan dengan seseorang yang aktivitas fisiknya sedang atau berat. Aktivitas fisik yang baik dan rutin akan melatih otot jantung dan tahanan perifer yang dapat mencegah hipertensi. Olahraga yang teratur dapat merangsang pelepasan hormon endorfin yang menimbulkan efek euphoria dan relaksasi otot sehingga tekanan darah tidak meningkat.

Terdapat perbedaan yang signifikan pada tekanan darah individu yang lebih aktif beraktivitas dibanding yang kurang aktif. Tekanan darah cenderung normal dengan aktivitas tinggi dari pada aktivitas rendah. Tekanan darah terbukti turun dengan melakukan aktivitas fisik secara reguler. Aktivitas fisik dengan intensitas sedang sampai intensitas tinggi menurunkan tekanan darah. Mekanisme penurunan tekanan darah yang terjadi karena melakukan aktivitas fisik dipercaya terjadi oleh berkurangnya resistensi perifer. Melakukan aktivitas fisik dapat mengurangi kerja saraf simpatif, pembuluh darah lebih sehat terhindar dari stress oksidatif dan peradangan, menekan aktivitas renin sehingga pembuluh darah vasodilatasi dan tekanan darah turun.

Berdasarkan hasil penelitian, kajian teori dan penelitian terkait maka dapat disimpulkan responden yang mempunyai aktivitas fisik ringan cenderung lebih besar berisiko terkena hipertensi tetapi begitu sebaliknya responden yang memiliki aktivitas fisik sedang cenderung lebih sedikit berisiko terkena hipertensi. Jadi aktivitas fisik responden sangat mempengaruhi terjadinya hipertensi pada responden.

\section{SIMPULAN}

Berdasarkan hasil penelitian di atas dapat disimpulkan bahwa tingkat aktivitas fisik pada pekerja yang bekerja dari rumah paling banyak ada pada kategori sedang sebanyak 31 responden (45.6\%). Tekanan darah pada pekerja yang paling banyak ada pada kategori normal sebanyak 26 responden (38.2\%). Ada hubungan tingkat aktivitas fisik dengan tekanan darah pada pekerja yang bekerja dari rumah selama masa pandemi Covid-9 di wilayah Kelurahan Seririt tahun 2021 dengan nilai $\rho$-value $=0.004$. 
Ni Made Wedri, Komang Ayu Windayanti, IGA Ari Rasdini. Juni 2021. 14

(1): $16-26$

\section{UCAPAN TERIMAKASIH}

Peneliti mengucapkan terima kasih kepada kepala Kelurahan Seririt serta staff yang telah memberikan izin dan membantu dalam melakukan penelitian di wilayah Kelurahan Seririt kepada semua pihak yang terlibat dan telah membantu dalam penelitian ini.

\section{ETHICAL CLEARENCE}

Persetujuan etika penelitian ini diperoleh dari komisi etik penelitian Politeknik Kesehatan Kemenkes Denpasar dengan nomor surat LB.02.03/EA/KEPK/0356/2021

\section{DAFTAR RUJUKAN}

1. Junaidi, I. (2010) 'Hipertensi, Pengenalan, Pencegahan, danPengobatan', Jakarta: PT Bhuana Ilmu Populer.

2. Dinas Kesehatan Provinsi Bali (2015) Profil Kesehatan Provinsi Bali Tahun 2014. Denpasar: Dinas Kesehatan Provinsi Bali.

3. Dinas Kesehatan Provinsi Bali (2018) Profil Kesehatan Provinsi Bali Tahun 2017. Denpasar: Dinas Kesehatan Provinsi Bali.

4. Dinas Kesehatan Kabupaten Buleleng (2019) Profil Kesehatan Kabupaten Buleleng. Singaraja: Dinas Kesehatan Kabupaten Buleleng.

5. Anggara, F. H. D. and Prayitno, N. (2013) 'Faktor-faktor Yang Berhubungan Dengan Tekanan Darah Di Puskesmas Telaga Murni, Cikarang Barat Tahun 2012', Jurnal Ilmiah Kesehatan, 5(1), pp. 20-25.

6. Kemenkes RI (2018a) 'Hasil Riset Kesehatan Dasar Tahun 2018', Kementrian Kesehatan RI, 53(9), pp. 1689-1699.

7. Dana, Y. E. (2018) 'Hubungan Aktivitas Fisik dengan Derajat Hipertensi pada Lansia (Studi di Dusun Pajaran Desa Peterongan Kecamatan Peterongan Kabupaten Jombang)'. STIKes Insan Cendekia Medika Jombang.

8. American Diabetes Association (2015) 'Physical Activity is Important'

9. KemenKes, R. I. (2017) Buku Panduan GERMAS Gerakan Masyarakat Hidup Sehat. jakarta: Kementerian Kesehatan RI.

10. Noviyanti. (2015). Hipertensi (Kenali, Cegah dan Obati. Yogyakarta : NOTEBOOK.

11. Martuti, A. (2009). Hipertensi Merawat Dan Menyembuhkan Penyakit Tekanan Darah Tinggi. Penerbit Kreasi Kencana Perum sidorejo Bumi Indah (SBI) Blok F 155 Kasihan Bantul, Pp.10-12.

12. Kozier, Erb, Berman, \&Synder. (2011). Buku Ajar Fundamental Keperawatan: Konsep, Proses \&Praktik (7 ed., Vol. 1). Jakarta : EGC.

13. Wibowo, D. S. (2009) Anatomi tubuh manusia. Grasindo

14. Kemenkes RI (2018a) 'Manfaat aktivitas fisik - Direktorat P2PTM'. 
Ni Made Wedri, Komang Ayu Windayanti, IGA Ari Rasdini. Juni 2021. 14 (1): $16-26$

Available at: http://www.p2ptm.kemkes.go.id/infographic-p2ptm/hipertensipenyakitjantung-dan-pembuluh-darah/manfaat-aktivitas-fisik.

15. Roberth Kowalksi (2010) 'Terapi Hipertensi'. Available at: https://books.google.co.id/books?id=7d0Ex0LAIc4C\&pg=PA83\&source=gb $\mathrm{s} \_$selected_pages $\& \mathrm{cad}=3 \# \mathrm{v}=$ onepage $\& \mathrm{q} \& \mathrm{f}=$ false . 